\title{
ANALISIS HUBUNGAN PENERAPAN PESAN GIZI SEIMBANG KELUARGA DAN PERILAKU KELUARGA SADAR GIZI DENGAN STATUS GIZI BALITA DI PROVINSI KALIMANTAN BARAT
}

\author{
(Relationship Analysis of The Implementation of Balanced Nutrition Messages Family and \\ Behavior Family Nutrition Awareness with Under Five Years Child Nutritional Status \\ in West Kalimantan Province)
}

\author{
Didik Hariyadi $^{1}$, M Rizal Damanik ${ }^{2^{*}}$, dan Ikeu Ekayanti ${ }^{2}$
}

1 Jurusan Gizi Politeknik Kesehatan Pontianak, Kemeterian Kesehatan Republik Indonesia.
${ }^{2 *}$ Alamat korespondensi: Departemen Gizi Masyarakat, Fakultas Ekologi Manusia, Institut Pertanian
Bogor, Bogor 16680. Telp: 0251-8621258; Fax: 0251-8622276
2 Departemen Gizi Masyarakat, Fakultas Ekologi Manusia, Institut Pertanian Bogor, Bogor 16680.

\begin{abstract}
The present study aims to analyze of relationship of the implementation of balanced nutrition messages family and behavior family nutrition awareness with under five years child nutritional status in West Kalimantan Province. The study uses Health Research Data Base of West Kalimantan Province in year 2007 with the design of cross-sectional study. The total of 1992 household samples were recruited in the study with criteria having child aged 6 to 59 months. Weight for height, weight for age and height for age indicators were used to measure child nutritional status. The results showed that three messages did not meet criteria as required by the Indonesian Food Guideines. Three messages did not meet criteria as required by the Indonesian Food Guidelines. They were eat food withr energy needs requaired, eat half of food sources of carbohydrate for energy needs and eating one of fourth of food sources of fat for energy needs. Logistic multiple regression analysis showed that failure to follow the the Family Nutrition Awareness had 1.21 risk for children to became stunting than family to follow to guideline properly.
\end{abstract}

Key words: under five years child, nutritional status, balanced nutrition messages, family nutrition awareness, Indonesian Food Guidelines.

\section{PENDAHULUAN}

Gizi merupakan salah satu penentu kualitas Sumber Daya Manusia (SDM). Makanan yang diberikan sehari-hari harus mengandung semua zat gizi sesuai kebutuhan, sehingga menunjang pertumbuhan yang optimal dan dapat mencegah penyakit defisiensi, mencegah keracunan dan juga mencegah timbulnya penyakit yang dapat mengganggu kelangsungan hidup anak (Soekirman 2000).

Masa bayi dan anak adalah masa mereka mengalami pertumbuhan dan perkembangan yang cepat dan sangat penting sebagai landasan yang menentukan kualitas generasi penerus bangsa (Azwar 2000).

Status gizi balita sangat dipengaruhi oleh lingkungan sosial terdekat. Di samping itu peran keluarga sangat besar dalam membentuk kepribadian anak. Pola pendidikan yang tepat yang diterapkan oleh orang tua akan sangat membantu anak dalam menghadapi kondisi lingkungan pada masa yang akan datang. Orang tua merupakan tempat bergantung anak-anaknya dan harus memberikan kasih sayang dan perhatian sepenuhnya pada anak hingga remaja.

Penyebab langsung status gizi yaitu makanan anak dan penyakit infeksi yang mungkin diderita anak. Penyebab gizi kurang tidak hanya disebabkan makanan yang kurang tetapi juga karena penyakit. Anak yang mendapat makanan yang baik tetapi sering menderita penyakit infeksi dapat menderita kurang gizi. Demikian pula pada anak yang makannya tidak cukup baik, maka daya tahan tubuh akan melemah dan mudah terserang penyakit. Sehingga makanan dan penyakit merupakan penyebab kurang gizi (Supariasa et. al. 2002).

Perilaku gizi yang baik dan benar pada tiap individu dapat mengacu pada pesan gizi seimbang dalam Pedoman Umum Gizi Seimbang (PUGS) yang terdiri dari 13 pesan (Depkes, 2005), meskipun untuk mendukung upaya penilaian dan pemantauan praktek pesan gizi seimbang perlu penelitian lebih lanjut tentang penilaian penerapan pesan-pesan gizi seim- 
bang untuk kelompok ibu hamil, anak sekolah, remaja dan usia lanjut (Hardinsyah, 1998).

Salah satu sasaran prioritas Rencana Strategi Departemen Kesehatan dalam rangka mencapai sasaran menurunkan prevalensi gizi kurang adalah Keluarga Sadar Gizi (KADARZI) (Depkes 2007) yang merupakan penyederhanaan dari pesan gizi seimbang (Minarto 2009).

Penelitian tentang penerapan pesan gizi seimbang dan pengaruh perilaku KADARZI terhadap status gizi balita khususnya di Kalimantan Barat belum pernah dilakukan. Hasil RISKESDAS di Kalimantan Barat 2007, ditemukan data sebagai berikut: prevalensi balita dengan gizi kurang dan buruk (underweight) berdasar berat badan menurut umur (BB/U) sebesar $22.6 \%$, status pendek dan sangat pendek (stunting) berdasar tinggi badan menurut umur (TB/U) mencapai 36.8\%, kurus dan sangat kurus (wasting) berdasar berat badan menurut tinggi badan (BB/TB) sebanyak $17.3 \%$, sedangkan prevalensi gizi lebih berdasar BB/U didapat sebesar $5 \%$ dan berdasarkan BB/TB 14\%. Secara nasional Kalimantan Barat termasuk salah satu dari 25 provinsi di Indonesia dengan prevalensi underweight, wasting, gizi lebih dan gemuk di atas rata-rata nasional (masing-masing 18.4\%, 13.6\%, 36.8\%, 4.3\% dan $12.2 \%)$.

Peneliti ingin melihat apakah penerapan gizi seimbang keluarga dan perilaku KADARZI rumah tangga balita mempunyai hubungan dengan status gizi balita dan apakah ada perbedaan determinan faktor penerapan gizi seimbang keluarga dan perilaku KADARZI hubungannya dengan Status Gizi balita. Penelitian ini bertujuan untuk menganalisis hubungan penerapan pesan gizi seimbang keluarga dan perilaku KADARZI terhadap status gizi balita di Provinsi Kalimantan Barat.

\section{METODE}

\section{Desain, Tempat, dan Waktu}

Jenis penelitian ini adalah penelitian observasional menggunakan data sekunder hasil
Riskesdas 2007 dengan desain cross sectional, dimana pengukuran outcome dan potential predictor dilakukan secara simultan pada waktu yang bersamaan (Aswin 1997) sesuai dengan desain Riskesdas 2007 di Provinsi Kalimantan Barat. Wilayah penelitian di Provinsi Kalimantan Barat yang dilaksanakan bulan Januari 2010 sampai Maret 2010.

\section{Jumlah dan Cara Penarikan Sampel}

Populasi dalam Riskesdas Provinsi Kalimantan Barat 2007 adalah seluruh rumah tangga di wilayah Provinsi Kalimantan Barat. Sampel adalah rumah tangga dan anggota rumah tangga yang diambil dengan menggunakan metodologi penghitungan dan cara penarikan sampel identik dengan two stage sampling yang digunakan dalam Susenas 2007. Setiap kabupaten/kota yang masuk dalam kerangka sampel kabupaten/kota, diambil sejumlah blok sensus yang proporsional terhadap jumlah rumah tangga di kabupaten/kota tersebut. Jumlah rumah tangga pada sebuah kabupaten/ kota diambil dengan metode probability proportional to size. Setiap blok sensus terpilih kemudian dipilih 16 (enam belas) rumah tangga secara acak sederhana.

Jumlah rumah tangga yang mempunyai balita berdasarkan data yang diperoleh dari Badan Penelitian dan Pengembangan Kesehatan (Balitbangkes) Depkes RI sebanyak 2.375 rumah tangga. Selanjutnya ditetapkan sampel rumah tangga dengan kriteria inklusi adalah rumah tangga yang mempunyai balita umur 6 59 bulan, mempunyai data BB dan TB dengan cut off point sesuai indikator z-score status gizi BB/TB, TB/U dan BB/U pada WHO (World Health Organization) Anthro 2009 dan mempunyai data sosial ekonomi dan pendidikan orang tua, sehingga jumlah sampel diperoleh sebanyak 1992 rumah tangga balita (Gambar 1).

\section{Pengolahan dan Analisis Data}

Pengolahan data pesan gizi seimbang mengacu pada cara penilaian penerapan 13 pesan PUGS Hardinsyah (1998) yang dimodifikasi. Data tentang pesan gizi seimbang yang

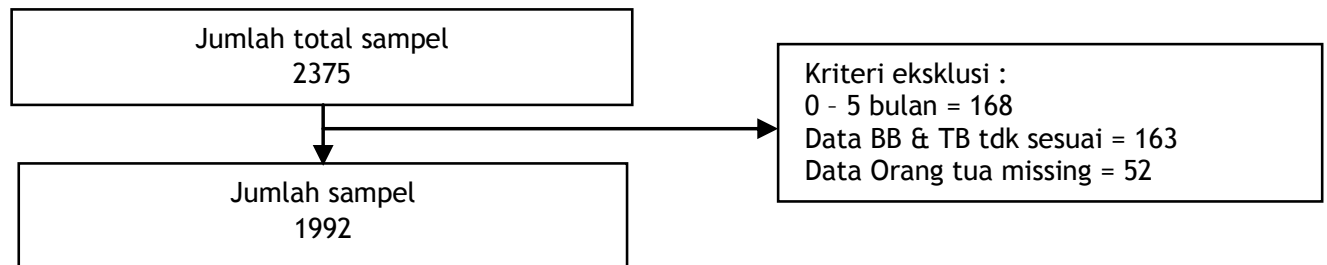

Gambar 1. Skema Jumlah dan Pengambilan Sampel 
diperoleh dari Riskesdas 2007 terdapat 8 pesan dari 13 pesan yang dapat dinilai, sedangkan 5 pesan yang lain tidak dapat diperoleh datanya. Delapan pesan tersebut adalah 1) Makanlah aneka ragam makanan; 2) Makanlah makanan untuk memenuhi kecukupan energi; 3) Makanlah makanan sumber karbohidrat setengah dari kebutuhan energi; 4) Batasi konsumsi lemak dan minyak $1 / 4$ dari kecukupan energi; 5) Gunakan garam beriodium; 6) Makanlah sumber zat besi; 7) Lakukan aktifitas fisik secara teratur; dan 8) Hindari minum minuman beralkohol. Masing-masing pesan diberi skor 1 , sehingga skor total adalah 8. Masing-masing pesan dikategorikan secara nominal dengan skor 0 , jika tidak memenuhi dan skor 1 jika memenuhi masing-masing pesan PUGS. Selanjutnya kategori penerapan gizi seimbang dikatakan baik jika total skor 4 - 8 dan kurang baik jika total skor < 4. Data perilaku KADARZI rumah tangga dikategori baik dan kurang baik menggunakan indikator yang dipakai Depkes (2007) dengan empat dari lima indikator pengukuran. Data Status gizi menggunakan kategori baku antropometri WHO (2006) yang didasarkan pada nilai $z$-score berdasarkan BB/TB, TB/U dan $\mathrm{BB} / \mathrm{U}$. Data infeksi yang diambil adalah data infeksi saluran pernapasan atas (ISPA), diare, demam thypoid, malaria, campak dan demam berdarah. Penilaian menggunakan kuesioner dengan menanyakan pernah menderita atau pernah didiagnosa oleh tenaga medis menderita. Selanjutnya dikategorikan pernah atau tidak pernah menderita satu atau lebih penyakit ISPA, diare, demam thypoid, malaria, campak atau demam berdarah. Data konsumsi gizi akan didasarkan pada kelompok zat gizi energi, protein dan vitamin A sesuai dengan ketersediaan data Riskesdas 2007. Selanjutnya kebutuhan masing-masing zat gizi dihitung berdasarkan kelompok umur menggunakan standar AKG tahun 2004.

Analisis data hasil penelitian disajikan dalam bentuk deskriptif dan inferensial. Analisis univariat untuk melihat distribusi frekuensi masing-masing variabel penelitian. Analisis bivariat digunakan untuk mengetahui hubungan antara masing-masing variabel independen dan variabel dependen. Uji kemaknan digunakan metode Chi-Square $\left(\chi^{2}\right)$ (Selvin, 1996). Analisis multivariat menggunakan regresi logistik ganda. Kriteria kemaknaan statistik yang dipakai adalah $\rho<0.05$. Nilai confidence interval $(\mathrm{Cl})$ ditetapkan $95 \%$. Pengolahan dan analisis data masing-masing menggunakan software Microsoft Office Excell 2007 dan software SPSS (Statistic Program for Social
Science) for windows versi 16.0 tahun 2007. Penentuan nilai $z$-score berdasarkan $B B / T B$, $\mathrm{BB} / \mathrm{U}$ dan TB/U menggunakan software Anthro WHO versi 3.0.1 tahun 2009.

\section{HASIL DAN PEMBAHASAN}

\section{Karakteristik Sampel}

Rata-rata umur balita dalam penelitian ini adalah $30.9 \pm 14.6$ bulan dengan kelompok umur tertinggi antara 25 - 43 bulan (37.9\%) dan jenis kelamin laki-laki $52.2 \%$. Berat badan rata-rata $12.1 \pm 3.7 \mathrm{~kg}$ dan tinggi badan $86.6 \pm$ $12.4 \mathrm{~cm}$. Prevalensi status gizi balita $(6-59$ bulan) yang diukur berdasarkan indeks $B B / T B$, $\mathrm{BB} / \mathrm{U}$ dan $\mathrm{TB} / \mathrm{U}$ menunjukkan bahwa sebagian besar balita mempunyai status gizi normal dan baik dibandingkan dengan kategori status gizi yang lain, masing-masing sebesar $70.4 \%, 73.2 \%$ dan 56.5\% (Tabel 1). Berdasarkan kriteria masalah gizi yang ditetapkan Depkes (2009) berdasarkan WHO, Kalimantan Barat menghadapi masalah gizi akut-kronis dengan karakteristik masalah gizi sebagi berikut : prevalensi balita wasting mencapai $17.0 \%$ (> 5\%), balita stunting mencapai $43.4 \%$ (> 20\%) dan balita status gizi underweight sebesar $24.1 \%$ (> 10\%) dengan prevalensi status infeksi balita di Kalimantan Barat menyebar antara yang infeksi dan tidak infeksi masing-masing $47.8 \%$ dan $52.2 \%$. Infeksi merupakan salah satu faktor penyebab langsung status gizi balita disamping konsumsi. Pada masa anak-anak yang sedang tumbuh umumnya akan mengalami lebih dari 100 macam infeksi sebelum mencapai masa dewasa. Kejadian ini akan lebih buruk jika terjadi pada daerah miskin, sanitasi yang buruk dan daerah dengan masalah gizi (Linder 1992).

Konsumsi energi dan vitamin A balita sebagian besar masih defisit (66.5\% dan 68.2\%) dibandingkan dengan konsumsi protein yang sebagian besar $(66.9 \%)$ sudah baik. Zat gizi protein merupakan salah satu zat gizi penting terutama pada masa pertumbuhan dan perkembangan balita. Kalimantan Barat merupakan salah satu wilayah yang kaya akan hasil laut dan sungai, sehingga dimungkinkan konsumsi protein balita lebih baik dari konsumsi energi dan vitamin $\mathrm{A}$.

Tabel 1 juga menunjukkan bahwa proporsi tingkat pendidikan orang tua balita baik ayah maupun ibu sebagian besar tamat SD atau dibawahnya masing-masing $60.9 \%$ dan $62.7 \%$ sedangkan pengeluaran rumah tangga rata-rata sebesar Rp $925000 \pm 426800$. 
Tabel 1. Sebaran Karakteristik Sampel

\begin{tabular}{|c|c|c|}
\hline & n (\%) & Mean \\
\hline \multicolumn{3}{|l|}{ Balita $(\mathrm{N}=1992)$} \\
\hline Umur (bulan) & & $31.5 \pm 14.6$ \\
\hline $6-24$ & $704(35.3)$ & \\
\hline $25-43$ & 777 (39.0) & \\
\hline $44-59$ & 511 (25.7) & \\
\hline \multicolumn{3}{|l|}{ Jenis Kelamin } \\
\hline Laki-laki & $1026(51.5)$ & \\
\hline Perempuan & $966(48.5)$ & \\
\hline Berat Badan (BB) & & $11.7 \pm 3.2$ \\
\hline Tinggi Badan (TB) & & $86.4 \pm 12.4$ \\
\hline Status Gizi (BB/TB) & & $-0.29 \pm 1.97$ \\
\hline Normal & $1403(70.4)$ & \\
\hline Kurus & $170(8.5)$ & \\
\hline Sangat Kurus & $169(8.5)$ & \\
\hline Gemuk & $250(12.6)$ & \\
\hline Status Gizi (BB/U) & & $-1.09 \pm 1.46$ \\
\hline Baik & $1459(73.2)$ & \\
\hline Kurang & $340(17.1)$ & \\
\hline Buruk & $140(7.0)$ & \\
\hline Lebih & $54(2.7)$ & \\
\hline Status Gizi (TB/U) & & $-1.34 \pm 2.44$ \\
\hline Normal & $1126(56.5)$ & \\
\hline Pendek & $389(19.5)$ & \\
\hline Sangat Pendek & 477 (23.9) & \\
\hline \multicolumn{3}{|l|}{ Status Infeksi } \\
\hline Infeksi & $952(47.8)$ & \\
\hline Tidak Infeksi & $1040(52.2)$ & \\
\hline \multicolumn{3}{|l|}{ Konsumsi $(\mathrm{N}=1879)$} \\
\hline Energi & & $675.6 \pm 676.2$ \\
\hline Baik ( $\geq 100 \%$ AKG) & $341(17.1)$ & \\
\hline Sedang (80 - 90\% AKG) & $129(6.5)$ & \\
\hline Kurang (70 - 79.9\% AKG) & $85(4.3)$ & \\
\hline Defisit (< $70 \% A K G)$ & $1324(66.5)$ & \\
\hline Protein & & $51.1 \pm 29.3$ \\
\hline Baik ( $\geq 100 \%$ AKG) & $1333(66.9)$ & \\
\hline Sedang ( 80 - 90\% AKG) & $73(3.7)$ & \\
\hline Kurang (70 - 79.9\% AKG) & $38(1.9)$ & \\
\hline Defisit $(<70 \% A K G)$ & $435(21.8)$ & \\
\hline Vitamin A & & $250.9 \pm 216.5)$ \\
\hline Baik ( $\geq 100 \%$ AKG) & $335(16.8)$ & \\
\hline Sedang (80 - 90\% AKG) & $125(6.3)$ & \\
\hline Kurang (70 - 79.9\% AKG) & $61(3.1)$ & \\
\hline Defisit (< 70\%AKG) & $1358(68.2)$ & \\
\hline \multicolumn{3}{|l|}{ Orang Tua $(\mathrm{N}=1992)$} \\
\hline \multicolumn{3}{|l|}{ Pendidikan Ayah } \\
\hline$\leq \mathrm{SD}$ & $1213(60.9)$ & \\
\hline SMP & $348(17.5)$ & \\
\hline$\geq S M A$ & $431(21.6)$ & \\
\hline \multicolumn{3}{|l|}{ Pendidikan Ibu } \\
\hline$\leq \mathrm{SD}$ & $1248(62.7)$ & \\
\hline SMP & $354(17.8)$ & \\
\hline$\geq S M A$ & $390(19.6)$ & \\
\hline Pengeluaran RT & & $925000 \pm 426800$ \\
\hline$\geq$ Rata-rata & $844(42.4)$ & \\
\hline$<$ Rata-rata & $1148(57.6)$ & \\
\hline
\end{tabular}

\section{Penerapan Pesan Gizi Seimbang}

Penerapan pesan gizi seimbang dari 8 pesan yang dinilai menunjukkan tingginya rumahtangga yang tidak memenuhi pesan nomor
2, 3 dan 4, yaitu makan makanan untuk memenuhi energi, makan makanan sumber karbohidrat $1 / 2$ dari kebutuhan energi dan konsumsi lemak dan minyak $1 / 4$ dari kecukupan energi masing-masing $60.1 \%$, $66.3 \%$ dan $76.5 \%$ sedang- 
kan pesan yang paling banyak terpenuhi adalah pesan nomor 8 (menghindari minum minuman beralkohol) mencapai $88.9 \%$ (Tabel 2). Konsumsi energi perkapita sebesar 1.644.1 \pm 654.2 kal, masih dibawah rata-rata nasional (1735.5 kal) sedangkan konsumsi lemak, karbohidrat dan zat besi masingmasing $34.9 \pm 30.2 \mathrm{gr}$, $272.8 \pm 118.9$ gr dan $5.5 \pm 3.4 \mathrm{mg}$.

Pesan gizi seimbang yang mengacu pada PUGS merupakan salah satu pengembangan strategi dalam mencapai perubahan pola konsumsi makanan yang ada di masyarakat dengan tujuan akhir adalah tercapainya status gizi masyarakat yang lebih baik (Depkes, 2005). Tidak ada satu jenis makanan apapun di dunia ini yang dapat memenuhi jumlah zat gizi yang dibutuhkan oleh tubuh manusia. Menkonsumsi makanan yang beraneka ragam sangat bermanfaat bagi kesehatan, sebab kekurangan zat gizi tertentu pada satu jenis makanan akan dilengkapi oleh zat gizi serupa pada makanan yang lain (Depkes, 2005) dan kekurangan satu jenis zat gizi dalam konsumsi makanan sehari-hari akan menyebabkan penggunaan zat gizi lainnya tidak optimal. Makan makanan yang kurang aneka ragam akan berdampak pada metabolisme zat-zat gizi yang lain terganggu, sehingga dalam waktu lama dimungkinkan akan berakibat timbulnya masalah gizi. Pada pesan menghindari minum minuman beralkohol dalam penelitian ini sejalan dengan penelitian Emilia (1998) di Ciomas kabupaten Bogor yang menunjukkan bahwa penerapan pesan gizi seimbang menghindari minum minuman beralko hol pada ibu sebesar 99\% tertinggi dibanding pesan lainnya.

Penerapan pesan gizi seimbang di rumah tangga balita secara umum masih kurang baik (52.6\%) (Tabel 3). Kondisi ini hampir sama dengan penelitian Hardinsyah et al (1998) yang mengemukakan masing-masing sekitar $45.2 \%$ bapak dan $49.1 \%$ ibu yang mempraktekkan 13 pesan gizi seimbang dengan baik.

Tabel 2. Sebaran Penerapan Pesan Gizi Seimbang Rumah Tangga

\begin{tabular}{lrc}
\hline \multirow{2}{*}{$\begin{array}{c}\text { Penerapan Pesan Gizi } \\
\text { Seimbang }\end{array}$} & \multicolumn{2}{c}{ Jumlah } \\
\cline { 2 - 3 } & \multicolumn{1}{c}{$\mathbf{n}$} & $\%$ \\
\hline Baik & 945 & 47.4 \\
Kurang Baik & 1047 & 52.6 \\
\hline
\end{tabular}

\section{Perilaku KADARZI}

KADARZI adalah suatu keluarga yang mampu mengenal, mencegah dan mengatasi masalah gizi setiap anggotanya (Depkes, 2007). Tabel 4 menunjukkan sebaran perilaku KADARZI rumah tangga dengan kriteria memenuhi dan tidak memenuhi. Perilaku menggunakan garam beriodium mempunyai proporsi tertinggi (86.1\%) dibanding dengan 3 perilaku lainnya (menimbang berat badan secara teratur, ma-

Tabel 3. Sebaran Penerapan Gizi Seimbang Rumah Tangga Berdasarkan Kriteria PUGS

\begin{tabular}{lcrrr} 
& \multicolumn{1}{c}{ Kriteria PUGS } & \multicolumn{3}{c}{ Kriteria } \\
\cline { 2 - 5 } & nemenuhi & \multicolumn{2}{c}{ Tdk memenuhi } \\
\cline { 2 - 5 } & $\mathbf{n}$ & \% & $\mathbf{n}$ & \% \\
\hline 1. Makan aneka ragam makanan & 1287 & 64.6 & 705 & 35.4 \\
2. Makan makanan untuk memenuhi & 795 & 39.9 & 1197 & 60.1 \\
$\quad \begin{array}{l}\text { kecukupan energi } \\
\text { 3. Makan makanan sumber karbohidrat }\end{array}$ & 672 & 33.7 & 1320 & 66.3 \\
$\quad$ setengah dari kebutuhan energi & & & & \\
4. Konsumsi lemak dan minyak 1/4 dari & 469 & 23.5 & 1523 & 76.5 \\
$\quad$ kecukupan energi & & & & \\
5. Menggunakan garam beriodium & 1715 & 86.1 & 277 & 13.9 \\
6. Makan sumber zat besi & 1064 & 53.4 & 928 & 46.6 \\
7. Melakukan aktifitas fisik secara teratur & 1515 & 76.1 & 477 & 23.9 \\
8. Menghindari minum minuman beralkohol & 1771 & 88.9 & 221 & 11.1 \\
\hline
\end{tabular}

Tabel 4. Sebaran Perilaku KADARZI Rumah Tangga Berdasarkan Indikator KADARZI

\begin{tabular}{lrrrr}
\hline \multirow{2}{*}{ Indikator KADARZI } & \multicolumn{4}{c}{ Kriteria } \\
\cline { 2 - 5 } & \multicolumn{2}{c}{ Memenuhi } & \multicolumn{2}{c}{ Tdk memenuhi } \\
\cline { 2 - 5 } & $\mathrm{n}$ & \multicolumn{1}{c}{$\mathrm{n}$} & $\%$ \\
\hline 1. Menimbang berat badan secara teratur & 516 & 25.9 & 1476 & 74.1 \\
2. Menggunakan garam beriodium & 1715 & 86.1 & 277 & 13.9 \\
3. Makan aneka ragam makanan & 1287 & 64.6 & 705 & 35.4 \\
4. Memberikan suplement gizi sesuai anjuran & 551 & 27.7 & 1441 & 72.3 \\
\hline
\end{tabular}


kan aneka ragam makanan dan memberikan suplement gizi sesuai anjuran). Penggunaan garam beriodium di Kalimantan Barat sudah lebih tinggi dari rata-rata nasional (24.5\%) meskipun belum sesuai target Universal Salt lodization 2010 sebesar $90 \%$.

Tabel 5 menunjukkan perilaku KADARZI rumah tangga balita, dimana kurang baik (56.9\%) lebih besar dibandingkan dengan perilaku KADARZI baik (43.1\%). Hasil ini sejalan dengan penelitian deskriptif yang telah dilakukan oleh Nurmayati (2002) di Kelurahan Betet Kota Kediri yang menyebutkan bahwa implementasi KADARZI hanya dilakukan oleh sebagian masyarakat dengan kendala faktor pendidikan dan ekonomi yang rendah.

Tabel 5. Sebaran Perilaku KADARZI Rumahtangga

\begin{tabular}{lcc}
\hline \multirow{2}{*}{ Perilaku KADARZI } & \multicolumn{2}{c}{ Jumlah } \\
\cline { 2 - 3 } & $\mathbf{n}$ & $\%$ \\
\hline Baik & 859 & 43.1 \\
Kurang Baik & 1133 & 56.9 \\
\hline
\end{tabular}

Hasil uji regresi logistik binary menunjukkan bahwa pengaruh penerapan pesan gizi seimbang keluarga terhadap status gizi pada indek $\mathrm{BB} / \mathrm{TB}, \mathrm{BB} / \mathrm{U}$ dan $\mathrm{TB} / \mathrm{U}$ tidak signifikan secara statisrtik. Perilaku KADARZI mempunyai pengaruh terhadap status gizi balita pada in- deks TB/U. Perbandingan nilai signifikan antara penerapan pesan gizi seimbang dan perilaku KADARZI dalam mempengaruhi status gizi balita pada indek TB/U masing-masing 0.49 ( $\rho>$ $0.05)$ dan $0.04(\rho<0.05)$. Analisis ini memberikan makna bahwa perilaku KADARZI merupakan faktor yang mempengaruhi status gizi balita pada indek TB/U. Perilaku KADARZI yang kurang baik mempunyai peluang risiko 1.21 kali terhadap kejadian stunting dibandingkan dengan perilaku KADARZI yang baik.

Status gizi balita dengan indeks TB/U adalah indikator masalah gizi kronis sebagai akibat dari keadaan yang berlangsung cukup lama (Depkes 2009), sehingga dampak dari perilaku KADARZI rumah tangga mempunyai kecenderungan mempengaruhi status gizi balita dalam jangka waktu yang panjang. UNICEF (1997) mengemukakan bahwa status gizi balita dipengaruhi secara langsung oleh 2 faktor yaitu konsumsi gizi dan infeksi. Dua faktor ini merupakan faktor yang dapat mengakibatkan masalah gizi akut. Perilaku KADARZI yang baik dalam rumah tangga balita dengan 4 indikator penilaian KADARZI berhubungan langsung dengan faktor konsumsi balita dan pemantauan berat badan sebagai indikasi dini terjadinya perubahan status gizi yang cepat yang disebabkan oleh faktor konsumsi dan infeksi.

Tabel 6. Hasil Analisis Regresi Logistik

\begin{tabular}{|c|c|c|c|}
\hline Variabel Independent & $\begin{array}{c}\text { Odds Ratio } \\
\text { Exp (B) }\end{array}$ & $\begin{array}{c}\text { Cofidence } \\
\text { Interval } 95 \%\end{array}$ & Sig. \\
\hline \multicolumn{4}{|c|}{$n=1992$} \\
\hline \multicolumn{4}{|c|}{ Variabel Dependent Status Gizi Indeks BB/TB } \\
\hline \multicolumn{4}{|c|}{ Penerapan Pesan Gizi Seimbang } \\
\hline Kurang Baik (1) & 1.08 & $(0.84-1.38)$ & 0.56 \\
\hline \multicolumn{4}{|l|}{ Perilaku Kadarzi } \\
\hline \multicolumn{4}{|l|}{ Baik (0) } \\
\hline Kurang Baik (1) & 0.79 & $(0.61-1.02)$ & 0.66 \\
\hline \multicolumn{4}{|c|}{ Variabel Dependent Status Gizi Indeks BB/U } \\
\hline \multicolumn{4}{|l|}{$\begin{array}{c}\text { Penerapan Pesan Gizi Seimbang } \\
\text { Baik (0) }\end{array}$} \\
\hline Kurang Baik (1) & 0.91 & $(0.73-1.14)$ & 0.43 \\
\hline \multicolumn{4}{|l|}{ Perilaku Kadarzi } \\
\hline Kurang Baik (1) & 0.98 & $(0.79-1.22)$ & 0.88 \\
\hline \multicolumn{4}{|c|}{ Variabel Dependent Status Gizi Indeks TB/U } \\
\hline \multicolumn{4}{|l|}{$\begin{array}{c}\text { Penerapan Pesan Gizi Seimbang } \\
\text { Baik }(0)\end{array}$} \\
\hline Kurang Baik (1) & 0.90 & $(0.77-1.26)$ & 0.49 \\
\hline \multirow{2}{*}{\multicolumn{4}{|c|}{$\begin{array}{r}\text { Perilaku Kadarzi } \\
\text { Baik (0) }\end{array}$}} \\
\hline & & & \\
\hline Kurang Baik (1) & 1.21 & $(1.01-1.46)$ & $0.04^{*}$ \\
\hline
\end{tabular}

* signifikan $\rho<0.05$ 
Beberapa rangkaian analisis tentang hubungan perilaku KADARZI, penerapan pesan gizi seimbang dan status gizi balita dapat mempertegas apa yang dikemukakan Minarto (2009) bahwa KADARZI merupakan penyederhanaan dari PUGS yang valid dan reliabel serta dapat diaplikasikan dalam rangka menanggulangi masalah gizi pada balita terutama pada masalah gizi kronis sebagai ciri dari indeks pengukuran status gizi balita TB/U.

Program KADARZI cenderung lebih aplikatif dan terukur dengan adanya indikator KADARZI sebagaimana yang telah ditetapkan dengan Kepmenkes RI No. 747/Menkes/SK/ $\mathrm{VI} / 2007$, meliputi menimbang berat badan balita secara teratur, Memberikan ASI eksklusif, makan aneka ragam makanan, menggunakan garam beriodium dan memberikan suplemen gizi sesuai anjuran. Hal ini juga didukung dengan beberapa program lain seperti posyandu yang mempunyai 5 kegiatan utama, yaitu Kesehatan Ibu dan Anak (KIA), Keluarga Berencana (KB), imunisasi, gizi dan pencegahan dan penanggulangan diare. Disamping itu terdapat beberapa kegiatan yang dapat mendukung program KADARZI yaitu penimbangan balita setiap bulan, pemberian makanan tambahan dan suplementasi gizi, penyuluhan gizi dan kesehatan serta pelayanan kesehatan dasar. Secara teknis kegiatan posyandu meliputi pendaftaran, penimbangan, pencatatan, penyuluhan dan pelayanan kesehatan (Depkes, 2006).

\section{KESIMPULAN}

Penerapan pesan gizi seimbang yang masih kurang terutama pada pesan konsumsi lemak dan minyak $1 / 4$ dari kecukupan energi, makan makanan sumber kerbohidrat $1 / 2$ dari kebutuhan energi dan makan makanan untuk memenuhi energi masing-masing $76.5 \%, 66.3 \%$ dan $60.1 \%$ sedangkan paling besar terjadi pada penerapan pesan menghindari minum minuman beralkohol $88.9 \%$, menggunakan garam beriodium $86.1 \%$, melakukan aktifitas fisik secara teratur $76.1 \%$ dan makan aneka ragam makanan 64.6\%. Perilaku KADARZI menggunakan garam beriodium dalam rumah tangga mempunyai proporsi lebih tinggi $(86.1 \%)$ dibandingkan dengan perilaku menimbang berat badan secara teratur, makan aneka ragam makanan dan memberikan suplement gizi sesuai anjuran. Secara umum terdapat $43.1 \%$ rumah tangga dengan perilaku KADARZI kurang baik dibandingkan dengan perilaku KADARZI baik.
Ada pengaruh signifikan perilaku KADARZI rumah tangga terhadap status gizi balita pada indeks TB/U $(\rho<0.05)$ sedangkan penerapan pesan gizi seimbang secara signifikan tidak berpengaruh terhadap status gizi balita pada indek $\mathrm{BB} / \mathrm{TB}, \mathrm{BB} / \mathrm{U}$, dan $\mathrm{TB} / \mathrm{U}$.

\section{DAFTAR PUSTAKA}

Azwar A. 2000. Review Peningkatan Penggunaan ASI dan MP-ASI. Bogor.

Aswin S. 1997. Metodologi Penelitian Kedokteran. FK, UGM, Yogyakarta.

[Depkes RI] Departemen Kesehatan Republik Indonesia. 2005. Pedoman Umum Gizi Seimbang (PUGS). Direktorat Bina Gizi Masyarakat. Jakarta

[Depkes RI] Departemen Kesehatan Republik Indonesia. 2007. Keputusan Menteri Kesehatan Republik Indonesia Nomor: 747/ Menkes/SK/VI/2007 Tentang Pedoman Operasional Keluarga Sadar Gizi Di Desa Siaga, Jakarta.

[Depkes RI] Departemen Kesehatan Republik Indonesia. 2008. Laporan Hasil Riset Kesehatan Dasar (Riskesdas) Propinsi Kalimantan Barat Tahun 2007. Badan Penelitian dan Pengembangan Kesehatan Departemen Kesehatan RI, Jakarta.

[Depkes RI] Departemen Kesehatan Republik Indonesia. 2008. Laporan Hasil Riset Kesehatan Dasar (Riskesdas) Indonesia Tahun 2007. Badan Penelitian dan Pengembangan Kesehatan Departemen Kesehatan RI, Jakarta.

[Depkes RI] Departemen Kesehatan Republik Indonesia. 2009. Buku Saku Gizi. Kapankah Masalah Ini Berakhir. Badan Penelitian dan Pengembangan Kesehatan, Jakarta.

Emilia E. 1998. Cara Penilaian Penerapan Pesan-pesan Pedoman Umum Gizi Seimbang (PUGS) pada Pasangan Usia Subur di Kecamatan Ciomas Kabupaten Bogor. [Tesis]. Pascasarjana. IPB. Bogor.

Hardinsyah 1997. Pengembangan Cara Penilaian Penerapan PUGS. Makalah pada PraWidya Karya Nasional Pangan dan Gizi VI. 4 November. Jakarta. 
Hardinsyah et al. 1998. Cara Sederhana Penilaian Praktek PUGS Bagi Pasangan Usia Subur. Media dan Gizi Keluarga, XXII (2) : 28 - 35. Bogor.

Linder. Maria C. 1992. Biokimia Gizi dan Metabolisme. Dengan Pemakaian secara Klinis. UI Press. Jakarta.

Minarto 2009. Keluarga Sadar Gizi Solusi Atasi Masalah Gizi. www Promkes. http:// www.promosikesehatan.com/?act=news \&id=489 [27 Nov 2009]

Nurmayati, Yeti. 2002. Implementasi Program Keluarga Sadar Gizi (KADARZI) Dalam Upaya Meningkatkan Kesejahteraan Keluarga (Studi Kasus Tentang Implementasi Program KADARZI di Kelurahan Betet Kota Kediri). [Abstrak]. Program Pasca sarjana. Universitas Sebelas Maret. Surakarta.
Soekirman. 2000. Ilmu Gizi dan Aplikasinya Untuk keluarga dan Masyarakat. Dirjen Pendidikan Tinggi. Jakarta.

Supariasa I, Bakri, Bachyar, Fajar, Ibnu. 2002. Penilaian Status Gizi. EGC Jakarta.

Selvin S. 1996. Statistical Analysis of Epidemiologic Data. Second Edition. Oxford : Oxford University Press.

UNICEF. 1998. The State of The World's Children 1998: Focus of Nutrition. Oxford Uiversity Press. UK.

Zahraini, Y. 2009. Hubungan Status KADARZI dengan Status Gizi Balita 12 - 59 Bulan di Provinsi DI Yogyakarta dan Nusa Tenggara Timur. [Skripsi]. UI. Jakarta. 